\title{
WAYS OF EXPRESSING VERBAL AGGRESSION IN CHINESE
}

\author{
FORMAS DE EXPRESSAR A AGRESSÃO VERBAL NO CHINÊS
}

\author{
FORMAS DE EXPRESAR LA AGRESIÓN VERBAL EN CHINO
}

\author{
Svetlana Yuryevna GLUSHKOVA ${ }^{1}$ \\ Adelya Aidarovna MUKHAMETZYANOVA ${ }^{2}$
}

\begin{abstract}
From the early childhood, people hear and learn impolite utterance and use it in a situated context. This article suggests the study of the phenomenon of impoliteness in Chinese language, about why and when people use impoliteness words. From the early childhood, we hear obscene language or impolite statements towards a person, situation, or some things. The article deals with statements that have an addressee and a listener. With the help of certain strategies that will be analyzed, the person attempts to influence on the other. In turn, statements are divided into certain categories, have their own nuances and frequency of use. The Chinese language is no exception. The frequency of using obscene language in Chinese is increasing dramatically, which is partly due to the widespread use of social networks and the Internet in general. People have the opportunity to write literature without censorship, to post angry comments under news and records, since it is possible to do this anonymously. We will analyze different kinds of Chinese obscene language, its types, usage contexts etc. In addition, we will try to give a clear definition of 'impoliteness' that combines all previous existing ones. We hope that this work will help in understanding the goals of verbal 'impoliteness', its specific points and ways of interpretation in writing, with the examples like comments and literary statements.
\end{abstract}

KEYWORDS: Impoliteness. Strategies and types. Obscene language. Chinese language. Interpretation in writing.

RESUMO: Desde a primeira infância, as pessoas ouvem e aprendem expressões indelicadas e as usam em um contexto situado. Este artigo sugere o estudo do fenômeno da "grosseria" na língua chinesa, sobre o porquê e quando as pessoas usam palavras grosseiras. Desde a primeira infância, ouvimos linguagem obscena ou afirmações indelicadas na direção de uma pessoa, situação ou algumas coisas. $O$ artigo trata de declarações que têm um destinatário e um ouvinte. Com a ajuda de certas estratégias que serão analisadas, a pessoa tenta influenciar o outro. Por sua vez, os enunciados são divididos em determinadas categorias, possuem nuances próprias e frequência de uso. A língua chinesa não é exceção. A frequência do uso de linguagem obscena em chinês está aumentando dramaticamente, o que se deve em parte ao uso difundido de redes sociais e da Internet em geral. As pessoas têm a oportunidade de escrever literatura sem censura, de postar comentários raivosos em notícias e registros, uma vez que é possivel fazer isso anonimamente. Analisaremos diferentes tipos de linguagem obscena

${ }^{1}$ Kazan Federal University (KPFU), Kazan - Russia. ORCID: https://orcid.org/0000-0002-5187-3632. E-mail: Glushkova-syu@gmail.ru

${ }^{2}$ Kazan Federal University (KPFU), Kazan - Russia. ORCID: https://orcid.org/0000-0002-4464-8509. E-mail: adelyaallen@mail.ru 
chinesa, seus tipos, contextos de uso etc. Além disso, tentaremos dar uma definição clara de "grosseria" que combina todas as anteriores existentes. Esperamos que este trabalho ajude a compreender os objetivos da 'grosseria' verbal, seus pontos especificos e formas de interpretação na escrita, com exemplos como comentários e declarações literárias.

PALAVRAS-CHAVE: Grosseria. Estratégias e tipos. Linguagem obscena. Lingua chinesa. Interpretação por escrito.

RESUMEN: Desde la primera infancia, las personas escuchan y aprenden expresiones descorteses y las usan en un contexto situado. Este artículo sugiere el estudio del fenómeno de la "descortesía" en el idioma chino, sobre por qué y cuándo la gente usa palabras de descortesía. Desde la primera infancia, escuchamos lenguaje obsceno o declaraciones descorteses en la dirección de una persona, situación o algunas cosas. El artículo trata sobre declaraciones que tienen un destinatario y un oyente. Con la ayuda de ciertas estrategias que serán analizadas, la persona intenta influir sobre la otra. A su vez, las declaraciones se dividen en determinadas categorías, tienen sus propios matices y frecuencia de uso. El idioma chino no es una excepción. La frecuencia de uso de lenguaje obsceno en chino está aumentando drásticamente, lo que se debe en parte al uso generalizado de las redes sociales e Internet en general. La gente tiene la oportunidad de escribir literatura sin censura, de publicar comentarios enojados bajo noticias y registros, ya que es posible hacerlo de forma anónima. Analizaremos diferentes tipos de lenguaje obsceno chino, sus tipos, contextos de uso, etc. Además, intentaremos dar una definición clara de "descortesía" que combine todas las anteriores existentes. Esperamos que este trabajo ayude a comprender los objetivos de la "descortesia" verbal, sus puntos especificos y formas de interpretación por escrito, con ejemplos como comentarios y declaraciones literarias.

PALABRAS CLAVE: La descortesía. Estrategias y tipos. Lenguaje obsceno. Lenguaje chino. Interpretación por escrito.

\section{Introduction}

Today, the percentage of the population using profanity continues to increase. According to studies, people begin to curse from childhood, adopting words from parents, TV, peers. Profanity is used in various situations, such as conflict, dissatisfaction with what is happening, dissatisfaction with living conditions, their status and same things. Despite the fact that many people understand the destructive properties of conflicts and aggressive behavior, they often find this as the most effective way to solve the problem. People often use verbal methods to express aggression, because speech can clearly and thoroughly show the speaker's emotions and convey them to the listener. That is why the study of the expression of aggression is very important in order to understand what methods are used in which case and what the speaker wants to express in one way or another. 
While many people believe that speech aggression is an indicator of a person's lack of education, low social status and tactlessness, studies have shown that this is also one of the artistic ways of expressing emotion. Artistic, because speech aggression is often expressed not only with the help of profanity, but also with the help of metaphors, comparisons, embellishments and hyperbolization.

The purpose of this article is to study the main ways of expressing aggression in the Chinese language, the strategies by which it can be expressed, the definition of the term 'impoliteness', as well as the search for its specific moments.

To achieve this purpose, we are set to do several tasks, such as: determine the meaning of 'impoliteness', identify methods and strategies by which speech aggression can be expressed; consider the functions and specific aspects of the expression of speech aggression, the types of its creativity, and also consider examples of speech aggression in the Chinese language and determine which methods and types they relate to; define how profanity can be veiled in writing and its role.

\section{Research methodology}

To study methods of expressing speech aggression, we applied a theoretical research method. Literary sources, linguistic research on the topic of verbal aggression, examples in fiction, as well as in the Internet space of Chinese resources and works of art were analyzed. Conclusions are based on theory using practice. In addition, a contextual method of text analysis was used to detect and interpret the functionality of profanity in aggressive terms. Vulgar words with their own significance and function were found, and types of expression of aggression based on context were studied.

\section{Results and discussion}

Today, there is no universally accepted definition of 'impoliteness', as its manifestation and understanding depends on the context of use. 'Impoliteness' is subjective and evaluative; everyone is trying to consider it through the prism of their own understanding of politeness, opposing these two concepts.

The expression of verbal aggression is always diverse in its motives, context, methods of formulation and results. In addition to intonation, timbre and pace of speech, the character 
traits of speech can also include features of lexical means. In addition, the formal aspect is determined by the topic, content and goals of the statement.

Summing up all well-known definitions of 'impoliteness', we can admit the following definition:

Rudeness is a negative demeanor towards explicit practices happening in explicit settings. It is supported by assumptions, wants and/or convictions about social association, including, specifically, how one individual's or a gathering's personalities are interceded by others in connection. Arranged practices are seen contrarily - considered 'discourteous' - when they strife with how one anticipates that they should be, the way one needs them to be and/or how one figures they should be. Such practices consistently have or are ventured to have passionate ramifications for in any event one member, that is, they cause or are dared to cause offense. Different variables can compound how hostile a discourteous conduct is taken to be, including for instance whether one comprehends a conduct to be unequivocally deliberate or not (CULPEPER, 2011, p. 23).

In everyday language, there are other labels related to the concept of impolite behavior, for example, bad manners, insolence, rudeness, harshness, disrespect, insult, dishonor, lack of culture, impudence, etc. 'impoliteness' covers all aspects of this expression of aggression.

In itself, verbal aggression often has a direct character. They connect with the process of adding swear words into speech. And the main motive is 'the desire to lower the interlocutor's social status or self-esteem, inflict moral damage, insult the interlocutor and, ultimately, achieve a change in the interlocutor's behavior' (GELVIS, 1990, p. 81).

Jonathan Culpeper identifies three types of expressions of 'impoliteness'. These types share the functions of conflicting interpersonal relationships, identities and social norms:

1) 'Affective impoliteness' (the speaker releases his anger at the listener, which creates a negative emotional atmosphere) (HUANG, 1987, p. 150).

2) 'Forced rudeness' (causes a restructuring between the speaker and the listener. In this way, the speaker benefits from the listener (CULPEPER, 2011, p. 28).

3) 'Entertaining rudeness'. (Occurs when the speaker teases the listener and uses his feelings to enjoy / satisfy (CULPEPER, 2011, p. 28).

Sherbinina (2003, p. 103) divide types of speech aggression into 2 kinds: strong and weak. Strong types include abuse, condemnation, gross demands, even screaming. This also includes vicious criticism, sharp jokes, and threats. Mild manifestations include exceptionally mild rejection and indirect insult. By the nature and method of expression, a distinction is made between explicit (open) and implicit (hidden) aggression. 
Sheigal (1999, p. 42) distinguishes the following three types of expressions of 'impoliteness':

1) Expressive - a direct, sometimes impulsive type.

2) Manipulative - the most conscious type, which is based on transformations of the original meaning.

3) Implicit - associated with a veiled expression of the communicative intention of the speaker.

As for the functions of 'impoliteness', they are strategic because they are used to insult individuals or groups, to delimit the social status of other participants in the discourse, whose subjective positions are questioned and denied (KIENPOINTNER, 1997, p. 263)

According to many scientists, the concept of 'politeness' and 'impoliteness' came from China. The word 'politeness' did not exist until the 20th century, but this does not mean that the phenomenon itself did not exist - it was, but no one gave it a definition, except that similar

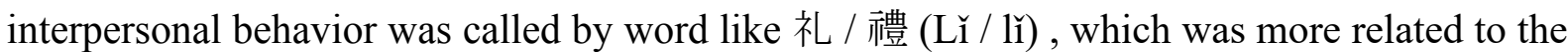
ability to be ceremonial.

So, verbal aggression in Chinese can be expressed by using 5 strategies, because 'impoliteness' is the using of strategies aimed at 'attack the face' and thereby causing social conflicts and disharmony. Jonathan Culpeper identifies five strategies by which 'impoliteness' implemented. We use them to classify strategies of 'impoliteness' in Chinese language:

1) 'Bald on record impoliteness'

This strategy is used when the speaker intends to 'damage the face' of the interlocutor and, therefore, the impolite statement will be used directly and clearly, like 'face-to-face attack' (BOUSFIELD, 2008, p. 92).

1. 你 的 演技不是一般 的 烂啊！ - (Your acting skills are amazingly awful!)

2. - '死鬼, 这么些天叫我夜夜等空门, 你把我忘啦?'- ('You are a devil! You keep me waiting all these days alone! Have you forgotten about me?') (DEYING, 2019, p. 458).

2) 'Positive impoliteness'

This strategy is used to damage the "positive face" of the listener (his desire to be accepted) (BOUSFIELD; LOCHER, 2008, p. 134) There are some sub-strategies that Jonathan Culpeper highlights:

- ignoring the interlocutor 
1. 范冰冰 自作自受! - (She asked for it herself!)

2. 馨予洗白了，这下轮到你们。风水轮流转。也报应你 俩上. - (Xinyu received her justice, now it is your turn. Retribution has come to you.) The statement did not deserve support and sympathy.

- selecting of undesirable topics for conversation;

- showing the disinterest of the listener and non-disposition towards him;

- Intentional searching for differences;

- using of obscure language and hidden, forbidden words (CULPEPER 2011: 26).

1. 真婊！ - ("Damn whore!)

The words taboo listed here are variants of 他妈的 (literally means “his mother"), which means "devil or shit" in Chinese (ZHONG 2018: 41).

3. 支持正义，打垮违法 戏 子！ - (I'm for justice. Deal with these criminal actors!) '戏 子' in Chinese is a derogatory nomination for an actor or actress. In Chinese feudal society, actors and actresses served as entertainment tools for officials.

3) 'Negative impoliteness'

This strategy is using to attack the 'negative face' of the listener (his desire to be free from imposition). It also has its own sub-strategies:

- an expression of contempt;

- an intentional desire to scare the interlocutor

1. 等着完蛋吧！ - (Just wait for your own day of doom!)

2. 等着进监狱吧！ - (Just wait until you are sent to jail!);

- mockery of the listener

1. 维权？ 根本 不 存在 的 好吗！ - (Protect legitimate rights? Some nonsense!)

- intruding into the interlocutor's space literally or metaphorically (CULPEPER, 2011, p. 26).

1. 取证的怎么样了? 什么时候告上法庭? 还是取证了半天发现崔永元 说 的 是 事实? - (How is the deposition going? When will you go to court? Is the bias against you?) 
2. 来解释一下怎么回事！ - (Come out and explain what happened!) By asking for information more than the closeness of the relationship allows, the speaker is trying to invade the recipient's personal space.

4) 'Sarcasm or mock impoliteness'

In this strategy, the speaker tries to offend the listener by using polite phrases that are clearly insincere. In other words, sarcasm means using one or more politeness strategies that are outwardly suitable and can be accepted, but in fact have the opposite meaning.

1. 偷税和 偷人 是演员们的强项. - (Tax evasion and fraud are what actors and actresses are good at.)

2. 厉害了我的国, 戏子天堂！ - (My country is so cool! Paradise of actors and actresses!)

5) 'Withhold impoliteness'

This strategy is applied when the speaker does not express polite words where it is expected. This, for example, happens when the speaker must thank the listener, but does not. This strategy is not often used in Chinese.

Strengthening of "impoliteness" is achieved through various language means: metaphors, idioms and comparisons. Exaggeration using negative nouns and adjectives has already been noted in studies of inciting hatred in the media (BUGARSKI, 1997, p. 154).

Offensive words in Chinese is '坏 语'. Unlike other languages, in Chinese branches there are several groups of swear words divided by using them in different expressions and contexts.

1) Words related to family. As a rule, the use of expressions may be associated with 'bald on record' impoliteness.

妈 的 (tā ma de) - 'F* ck'. Back in the 1920s, countries were known as the routinist of the country.

肉你祖宗十八 代 (cào nǐ zǔ zōng shí bā dài) is the oldest of the expressions. It means 'to hell your ancestors until the 18th generation.' These Chinese people deeply respect their ancestors, and this will almost certainly lead to a fight. 
2) Egg. There are many insults related to eggs. Expressions of this group are more suitable for the type of 'entertaining impoliteness' and 'negative impolite'.

a) 王八 (wáng bā) - roughly translated as 'bastard'.

b) 坏蛋 (huay dan) - literally means 'bad egg'. Used to call someone evil or just a completely bad person.

3) Words related to act of sexual nature. This group of words is probably one of the most offensive and vulgar.

a)二屄 (er bī) - is used to call someone the equivalent of a 'fucking idiot'.

b) 卖豆腐 (may du fu) - 'selling tofu' is used as a euphemism for prostitution.

c) 花花公子 (huā huā gōng zǐ) - it is translated as 'playboy', 'it can be used both with a negative and with a positive rating'.

4) Mixed words.

a) 我肉 (wǒ cào) - literally 'I f* ck'. This can mean a variety of things, such as 'shit of the God!', 'Damn cool!'.

b) 牛房 (niú bī) - for some reason, the cow's genitals means 'damn cool' in Chinese.

c) 吃单 (chi she) - 'eat shit'. The expression is extremely offensive, with the call to omit his 'face'.

Profanity or abusive language is often found on social networks and independent sources, especially when users can write things anonymously. Below are examples of disguising words on a letter.

1) Phrases with the word '幹 'f* $\mathrm{ck}$ ' replaced by '可恶'.

“幹你老師” (f* ck of your teacher). The writer only wants to express his anger, so it can be replaced with the words 'hell' or 'ugly man' ('可恶'). Instead of “幹 我 今天 ...”, we write “可恶 我今天 ...”, which will mean “Oh no, today ...”.

2) Phrases containing relatives. The original phrase in this category is '他妈的' ('shit', literally like 'to your mother'). Such phrase can be used as a possessive form in a formal text, and it will be written as "你 的 ...". 
3) Words synonymous with the words '婊子' 'B * tch'.

In this category, expressions are used to scold someone, so they can be replaced with phrases like 'bad person', which are less offensive. For example, you can replace the phrase using '坏人', which means 'bad' in translation.

Periphrase is a good way to hide your aggression on a letter, if you want the message reach the addressee and not be deleted.

\section{Summary}

All in all, we have found that each classification is divided into its own special elements, starting from the speaker's goal, ending with the result and effect over the interlocutor. We also have written a definition of 'impoliteness'. In the verbal expression of aggression in Chinese language, 4 methods of 'impoliteness' are used. Each of them pursues its own goals, methods, how to hurt, humiliate or ridicule a person. The methods, as a rule, depend on the context and will vary in certain circumstances. But they all have one goal - to cause an emotional harm to the addressee, using a verbal expression of aggression.

We also found that in Chinese profanity is divided into categories that are combined by the presence of the same word in each individual phrase. Each phrase, despite the presence of similar words, has its own special meaning and plays a unique role. Some phrases may be rougher, others, on the contrary, are softened and have several meanings. In addition, we found that the swear vocabulary can be veiled in writing, by several methods, as a rule they replaced by words with softer ones in meaning. This allows to express aggression more safely when you need to express your opinion not anonymously. We found that 'impoliteness' is not a trivial use of swear words and is not a colorless phenomenon. It may well be literary, since it is often used in fiction, as well as in the media, where it is necessary to embellish a negative assessment of a particular phenomenon.

\section{Conclusions}

'Impoliteness' is a negative attitude to a certain behavior, to the current reality in certain situations. It is supported by the expectations of others about how the speaker should behave in context. 'Impoliteness' always entails consequences for at least one participant, causing resentment. 
In addition, the study revealed that verbal aggression in Chinese has five strategies that can 'attack' the listener: 'Uncovered on record lack of consideration', 'positive rudeness', 'negative discourteousness', 'mockery or false rudeness', 'retain lack of consideration'. Each strategy has its own goals to create disharmony. In addition to the five strategies, there are 3 ways that can be used to express verbal aggression: 'affective impoliteness', 'forced rudeness', 'entertaining rudeness'. These types reveal how and with what we can express 'impoliteness' in relation to the listener (MUHAMETZYANOV; USMANOVA, 2018).

It was found that expressions with an aggressive context, as mentioned above, are often supported by artistic paths, such as metaphor, comparison, hyperbolization, etc.

We found that in Chinese; swear words are partitioned into classifications dependent on the recurrence of utilizing similar expressions in various articulations, each of which plays a role. We also looked at examples of veiling various vulgar expressions. There are several ways to veil, each of which has its own nuances, for example, replacing swear words with ordinary ones that do not have a bad meaning separately, but sound rude in context and so on.

We can conclude that Chinese language, like any other, is very rich in various expressions of aggression. Each expression has its own meaning, is used in a certain context and belongs to its classification.

ACKNOWLEDGEMENTS: The work is performed by the Russian Government Program of Competitive Growth of Kazan Federal University.

\section{REFERENCES}

BOUSFIELD, D. Impoliteness in interaction. Philadelphia and Amsterdam: John Benjamins, 2008.

BUGARSKI, R. Language in context. Belgrade, 1997.

CULPEPER, J. Impoliteness: using language to cause offence. Cambridge University Printing House, 2011.

DEYING, F. Winter Jasmine. Shandong Publishing House of literature and Art, 2019.

HUANG, K. Face and favor: the chinese power game. The American Journal of Sociology, v. 92, n. 4, 1987. DOI: doi.org/10.1086/228588

KIENPOINTNER, M. Varieties of rudeness: types and functions of impolite utterances. University of Innsbruck, 1997. 
MUHAMETZYANOV, R. R.; USMANOVA, I. R. The problem of destiny in ancient chinese philosophy. Revista Publicando, v. 5, n. 16, p. 617-622, 2018.

SHERBININA, Y. Problems of verbal aggression in the communication of students. Moscow: Forum, 2003.

ZHONG, W. Linguistic impoliteness strategies in sina weibo comments. Beijing Foreign Studies University, 2018.

\section{How to reference this article}

YURYEVNA, S. G.; MUKHAMETZYANOVA, A. A. Ways of expressing verbal agression in chinese. Rev. EntreLínguas, Araraquara, v. 07, n. 00, e021061, Sep. 2021. e-ISSN: 24473529. DOI: https://doi.org/10.29051/el.v7iesp.3.15732

Submitted: 10/01/2021

Required revisions: $20 / 03 / 2021$

Approved: 23/06/2021

Published: 01/08/2021 